\title{
The occurrence of heavy metals and metal-resistant bacteria in water and bottom sediments of the Straszyn reservoir (Poland)
}

\author{
Eliza Kulbat $^{1, *}$, Aleksandra Sokołowska ${ }^{1}$ \\ ${ }^{1}$ Gdańsk University of Technology, Narutowicza 11/12, 80-233 Gdańsk, Poland
}

\begin{abstract}
The aim of this study is to investigate the distribution of selected heavy metals and metal-resistant bacteria in water and bottom sediments of the surface drinking water reservoir for Gdańsk. The following sequence of metals in regard to metal concentration in sediments can be written down: $\mathrm{Zn}>\mathrm{Pb}>\mathrm{Cu}>\mathrm{Cd}$. The evaluation of metals accumulation was performed using the Müller index, to indicate the bottom sediment's contamination and geochemical classification of sediment quality according to Polish standards. The Müller geochemical index was changing in a wide range: $<1-4.1$. Although the maximum value of Müller's geochemical index determined for copper indicates that the sediment is 'strongly contaminated', in general the analysed bottom sediments were classified as the I and II category according to Polish geochemical standards. From the microbiological side a significant part of heterotrophic bacteria isolated from the bottom sediment and surface water (raw and treated water) showed a resistance to $0.2 \mathrm{mM}$ and $2 \mathrm{mM}$ concentrations of zinc, copper and lead. The highest percentages of metalresistant bacteria were recorded in the sediments of the reservoir $(60 \%-88 \%)$. The share of metal-resistant strains in the raw water was significantly lower $(34 \%-61 \%)$. The results indicate also that water treatment processes may contribute to the selection of resistant strains.
\end{abstract}

\section{Introduction}

Heavy metals are one of the most widespread contaminants in the environment. They cause the environmental pollution from sources such as industrial effluents, mine tailings, land application of fertilizers, atmospheric deposition and leaching of metal ions from the soil into lakes and rivers by acid rain [1-3]. The authors of many papers report the impact of heavy metals on aquatic communities including bottom sediments of rivers and lakes [4-9]. Numerous natural and anthropogenic factors affect the chemical composition of surface water sediments [10-12]. In the case of flow-through lakes often the most important material is the suspended and dissolved one, transported by supplying river, especially passing through urban, rural or agricultural areas [9]. The composition of sediments depends on geological structures, geomorphology and weathering process, so the

${ }^{*}$ Corresponding author: ekul@pg.gda.pl 
background values of individual compounds are characteristic for each region. Sediments accumulate contaminants like metals and can serve as secondary sources of pollution to the ecosystems they are connected with. The potential mobility of heavy metals depends on the physio-chemical conditions like $\mathrm{pH}$ and Eh level, temperature or presence of organic and mineral ligands [9, 13-15]. In addition, flow interruptions, storm events and other perturbations such as ice scouring can result in heavy metals being released again from the sediments. The desorption and transformation of contaminants into more bioavailable chemical forms may pose ecological risk. Although some heavy metals are required for the normal functioning of bacteria, fungi, plants and animals $[16,17]$ most can be toxic to all branches of life. The environmental pollution as well as the widespread use of antibiotics promote the formation of the mechanisms of resistance in bacteria. Drinking-water treatment plants use a number of treatment methods to improve water quality: e.g. flocculation, sedimentation, filtration and disinfection. Among the processes, chemical disinfection contributes greatly to the control of microorganisms from treatment plant to point of use [18]. It can promote however the survival of bacteria resistant to chlorine compounds, antibiotics as well as heavy metals.

Bottom sediments are good indicators of the contamination degree of the water environment. The assessing of concentrations of heavy metals and comparing them with background or reference value can be applied to determine the sediment contamination. There have been numerous criteria of sediment quality and some of them have been found to be a relatively good predictors of site contamination $[19,20]$. The most commonly used are Muller's index of geoaccumulation $\left(I_{\text {geo }}\right)[9,15,21]$, but in some countries (Poland, Germany) also the regional criteria are employed [22, 24].

The main objectives of this study are: to determine the concentration of heavy metals including $\mathrm{Zn}, \mathrm{Cu}, \mathrm{Pb}$ and $\mathrm{Cd}$ in the surface sediments of Straszyn lake, to assess the threshold of heavy metals contamination in sediments using the sediment quality criteria and to determine heavy metal resistant bacteria $(\mathrm{Cu}, \mathrm{Zn}, \mathrm{Pb})$ in bottom sediments, raw water and drinking water.

\section{Study area}

The study was conducted on Straszyn Lake located on the Radunia river (the northern Poland) on the eastern edge of the Kashubian Lakes District. This reservoir has been constructed in 1910 mainly to produce energy. Situated here a small hydroelectric power plant with a capacity of $2450 \mathrm{~kW}$ is the oldest one on the Radunia river and remains in operation until today. The Radunia's catchment area equals to $837 \mathrm{~km}^{2}$ and as much as $67.6 \%$ of the area is agricultural land. The total volume of Straszyn reservoir is $3 \mathrm{mln} \mathrm{m}$, surface area amounts to $0.75 \mathrm{~km}^{2}$ and the average retention time is 170 hours [25]. Since 1986 the main function of this reservoir is drinking water provision for several districts of Gdańsk.

The Straszyn surface intake is one on the biggest in Gdańsk and supplies the drinking water to more than $30 \%$ of the inhabitants [26]. During the research the raw water was pretreated with the ozone $\left(0.5-0.8 \mathrm{gO}_{3} / \mathrm{m}^{3}, 3 \mathrm{~min}\right.$.). After the coagulation ( $10 \%$ solution of $\mathrm{Al}_{2}\left(\mathrm{SO}_{4}\right)_{3}$ in summer or $5 \%$ solution of $\mathrm{NaOH}$ in winter) and flocculation processes in two-staged labyrinthine chambers, the water was filtered through sand and then intermediate ozone and filtration through activated carbon (up to $6 \mathrm{~m} / \mathrm{h}$ ) was applied. Prior to delivery to the network, polyphosphates and lime water were added to the treated water and then it was disinfected with mixture of $\mathrm{Cl}_{2}$ and $\mathrm{ClO}_{2}$. 


\section{Materials and methods}

\subsection{Samples collection}

Heavy metals concentration $(\mathrm{Zn}, \mathrm{Cu}, \mathrm{Pb}, \mathrm{Cd})$ was determined in sediments and presence of potentially heavy metals resistant bacteria was determined in the bottom sediments, raw water and water in distribution system.

\subsubsection{Sample collection of sediments}

Sediments sampling sites were located in the mainstream of reservoir. The ordinal numbers of the points increase from the Radunia river inflow to the water intake at the dam. The sampling locations are shown in Fig. 1.

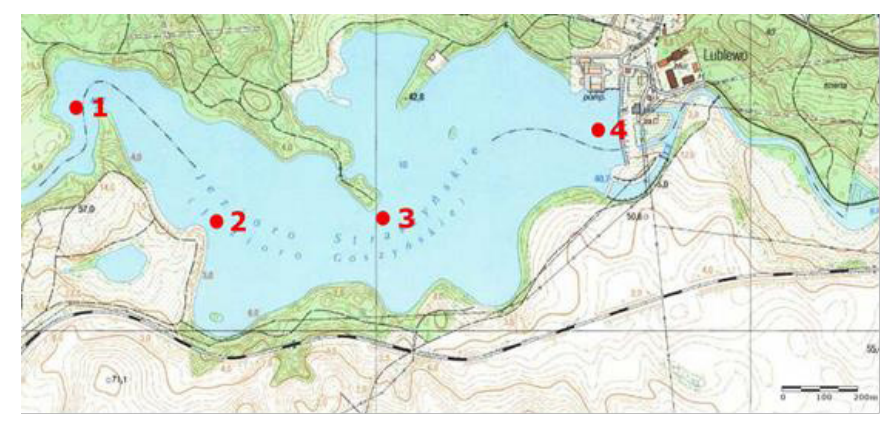

Fig. 1. Positions of sampling sites.

Surface sediment sampling was performed between May and October 2013, 8 times, in approximately 20 days intervals. Sediment samples of 10-15 cm thickness were collected using the KC Kajak sediment core sampler (Denmark Research Equipment) and stored in acid washed plastic containers. After collection samples were air-dried and sieved $(2 \mathrm{~mm}$ plastic sieve) in order to remove major detritus. A sterilized stainless steel $10 \mathrm{~cm}$ diameter sampler was used for collecting sediments for the microbiological analyses.

\subsubsection{Sample collection of water}

The raw water was collected after the screens, and the treated water was collected at five points chosen on the length of the network - there were downloaded 8 series of samples in total. The water samples were collected directly into sterile $500 \mathrm{ml}$ glass bottles.

\subsection{Laboratory analyses}

The samples of sediments were analyzed in terms of grain size, organic matter content and selected heavy metals content $(\mathrm{Zn}, \mathrm{Cu}, \mathrm{Pb}, \mathrm{Cd})$.

Grain size distribution was performed using wet sieving method (sand: $1-0.05 \mathrm{~mm}$, clay silty: $0.05-0.002 \mathrm{~mm}$, clay $<0.002 \mathrm{~mm}$ ) in Analysette 28 Image Sizer. Organic matter content was determined using loss of ignition (LOI) technique at $605^{\circ} \mathrm{C}$.

For metal analyses the sediment samples were dried at $105^{\circ} \mathrm{C}$ (to constant weight) and sieved through a $0,2 \mathrm{~mm}$ sieve. In order to determine the content of $\mathrm{Zn}, \mathrm{Cu}, \mathrm{Pb}$ and $\mathrm{Cd}$ the sediment samples were extracted with aqua regia $\left(\mathrm{HCl}: \mathrm{HNO}_{3}=3: 1\right)$ using Büchi digestion system K-438 [27]. All the concentrated acids used for the experiments were supra pure (Merck) quality. $\mathrm{Zn}, \mathrm{Cu}, \mathrm{Pb}$ and $\mathrm{Cd}$ standard solutions were prepared from $1000 \mathrm{mg} \cdot \mathrm{L}^{-1}$ 
Merck standard solution (Certipur $\left.{ }^{\circledR}\right)$. Blank reagent and reference materials analysis were done following the same experimental procedure.

Total metals concentrations in sediments were measured by flame atomic absorption spectrometry (FAAS) using Vario 6 (air/acetylene flame), equipped with a single element hollow cathode lamp and a deuterium lamp for the background correction. All measurements were performed three times and reported as mean values. Replicate measurements agreed within $<5 \%$. Accuracy of the analytical method was assessed using the sediment reference materials (river clay sediment LGC6139). During metals analyses, calibration solutions, blanks and standards were re-run every 12 samples. In studies of bacterial resistance to heavy metals there were used sulfate salts of zinc, copper and lead. The total number of bacteria was isolated on R2A agar [28]. Heterotrophic bacteria in water and sediment samples were enumerated by spread plate count. The plates were incubated at $22^{\circ} \mathrm{C}$ from 3 to 7 days. The sulfate salts of zinc, copper and lead were used as follows: the appropriate volumes of stock $10 \mathrm{mM} \mathrm{ZnSO}, 10 \mathrm{mM} \mathrm{CuSO} 4$ and $10 \mathrm{mM} \mathrm{Pb}\left(\mathrm{NO}_{3}\right)_{2}$ solutions, sterilized via filtration, were added to a $100 \mathrm{ml}$ sterile R2A liquid medium 15 minutes before inoculation in order to give a final concentration in solution $0.2 \mathrm{mM}$ and $2 \mathrm{mM}$. The percentages of metal-resistant bacteria were determined by comparing the number of bacteria on the $\mathrm{R} 2 \mathrm{~A}$ medium with $\mathrm{Cu}, \mathrm{Pb}$ and $\mathrm{Zn}$ with the number of bacteria on the R2A medium without them. $100 \mathrm{~g}$ sediment samples were mixed with $100 \mathrm{ml}$ of Ringer solution with $0.28 \%$ sodium pyrophosphate additive $[29,30]$. The solution was shaken vigorously for 20 minutes with a type 358S laboratory shaker and decanted for 2 minutes.

\section{Results and discussion}

Grain size analyses revealed that sediments sampled from the site 1 (upper part of reservoir, Fig. 1) were coarser (fraction 'sand' $47 \%$ and 'clay silty' $49 \%$ ) than sediments taken from the sites 2-4. Sediments from the middle and lower part of reservoir were finer, with the fraction 'clay silty' representing about $83 \%-91 \%$ of the sediment mass. The organic matter content (express as LOI) presented variability in the range of $10.6-14.8 \%$. $\mathrm{Zn}, \mathrm{Cu}, \mathrm{Pb}$ and $\mathrm{Cd}$ occurred in the investigated sediments in a wide range of concentration. Taking into consideration the criterion of the concentration in sediments, the following sequence of metals can be identified: $\mathrm{Zn}>\mathrm{Pb}>\mathrm{Cu}>\mathrm{Cd}$. The content of $\mathrm{Zn}$ in the sediments of the Straszyn reservoir were characterized by considerable variability $\left(15.31-92.47 \mathrm{mg} \mathrm{kg}^{-1} \mathrm{dry}\right.$ $\mathrm{wt})$. The mean $\mathrm{Zn}$ contents for sampling points were lower in the upper part of the reservoir compared to the middle and lower part (Fig. 2). Concentrations of $\mathrm{Cu}$ were in the range $2.34-25.65 \mathrm{mg} \mathrm{kg}^{-1} \mathrm{dry} \mathrm{wt}$; similar on the stations $2-4$ (mean values $20.40-22.05 \mathrm{mg} \mathrm{kg}^{-}$ ${ }^{1}$ dry wt) and lower on the station 1 (mean value $3.81 \mathrm{mg} \mathrm{kg}^{-1} \mathrm{dry} \mathrm{wt}$ ). The highest $\mathrm{Pb}$ content (mean value $33.75 \mathrm{mg} \mathrm{kg}^{-1}$ dry $\mathrm{wt}$ ) was detected in the sediments from the middle part. Concentration of $\mathrm{Cd}$ were in the range $0.04-1.70 \mathrm{mg}$ kg-1dry wt. Higher contents of $\mathrm{Cd}$ were found also in the middle and lower part of reservoir (from stations 2-4). Fig. 2 shows changes in the total metal content in sediments at the sampling sites.

Similar results were found in other investigations conducted in the sediments of lakes in the northern and northeastern Poland. There were observed though significant differences in heavy metals concentrations in bottom sediments in Poland: sediments of lakes and rivers located in southern Poland were more strongly contaminated by various metals in comparison to northern Poland [9, 24, 31]. 


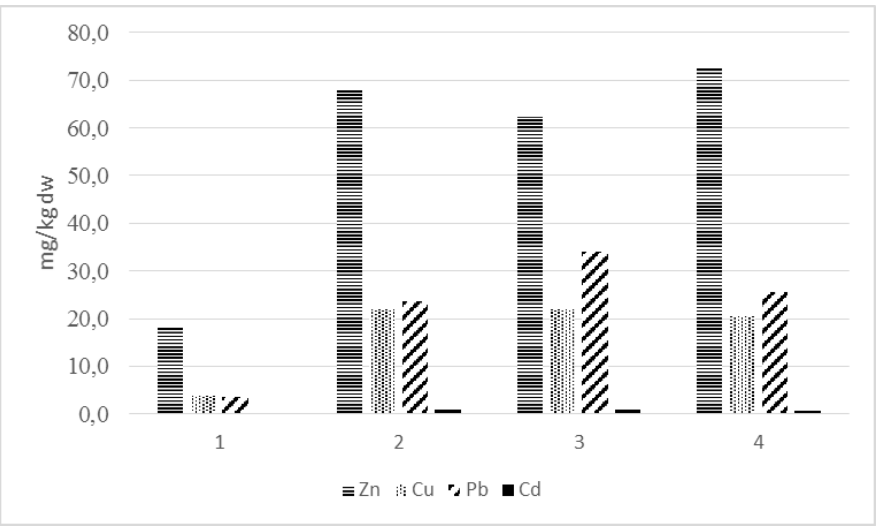

Fig. 2. Changes in the concentrations of zinc, copper, lead and cadmium in sediments at the sampling sites.

The earlier studies (1999-2000) of heavy metals in sediments of Straszyn lake [32] indicated that the concentrations of $\mathrm{Zn}, \mathrm{Cu}, \mathrm{Pb}$ and $\mathrm{Cd}$ were higher than the average ones for the Pommeranian Region. In our reserch, (conducted 14 years later) the concentrations of zinc, lead and cadmium were significantly lower and the content of copper was at a comparable level. The improvement of the quality of sediments was probably caused by the modernization and expansion of municipal facilities located in the catchment of the Radunia River: wastewater treatment plants in Przodkowo (2001-2002) and in Somonino (2008-2009). The reports of Gdańsk Inspectorate of the Environmental Protection [33] provided that in 2000 water quality of Radunia river was maintained in I and II class according to the Polish standards, but the concentration of copper was too high. The report on 2013 assesses the condition of the Radunia River's water in accordance with the WFD as good. Kuriata-Potasznik [9] reported that a river flowing through a lake is a key factor responsible for the input of the majority of available fraction of heavy metals.

According to the correlation coefficients, accumulation of heavy metals in the Straszyn reservoir sediments was mainly related to content of fine fraction of sediments: silty clay $\left(r^{2}=0.92-0.99\right)$ and clay fractions $\left(r^{2}=0.68-0.87\right)$. Similar results were obtained for $\mathrm{Cu}$, $\mathrm{Zn}, \mathrm{Pb}, \mathrm{Cd}$ and $\mathrm{Ni}$ by Szarek-Gwiazda and Strzebońska [15, 34]. Additionally a strong negative correlation was found between metals and sand fraction $\left(\mathrm{r}^{2}=-0.90--0.99\right)$. The high correlation coefficients between metals were also calculated $\left(\mathrm{r}^{2}=0.86-0.98\right)$ (Tab. 1).

Table 1. Coefficients of correlation between heavy metals concentration and between heavy metals concentration and parameters affecting metals distribution in the sediments.

\begin{tabular}{|c|c|c|c|c|c|}
\hline \multirow{2}{*}{ Parametr } & $\mathbf{Z n}$ & $\mathbf{C u}$ & $\mathbf{P b}$ & $\mathbf{C d}$ \\
\cline { 3 - 6 } & \multicolumn{4}{|c|}{$\mathbf{r}^{\mathbf{2}}$} \\
\hline \multicolumn{2}{|c|}{$\mathbf{Z n}$} & & 0.97 & 0.88 & 0.95 \\
\hline \multicolumn{2}{|c|}{$\mathbf{C u}$} & & & 0.95 & 0.98 \\
\hline \multicolumn{2}{|c|}{$\mathbf{P b}$} & & & & 0.86 \\
\hline \multirow{2}{*}{$\begin{array}{c}\text { Grain } \\
\text { size }\end{array}$} & $\mathbf{0 . 0 5}-\mathbf{1 . 0 0}$ & -0.99 & -0.96 & -0.92 & -0.90 \\
\cline { 2 - 6 } & $\mathbf{0 . 0 0 2 - 0 . 0 5}$ & 0.99 & 0.97 & 0.93 & 0.92 \\
\cline { 2 - 6 } & $\mathbf{0 . 0 0 2} \mathbf{~ m m}$ & 0.87 & 0.75 & 0.71 & 0.68 \\
\hline \multicolumn{2}{|c|}{ LOI } & 0.23 & 0.21 & 0.45 & 0.00 \\
\hline
\end{tabular}

The assessment of sediment enrichment with metals was carried out using Polish geochemical classification [24] and Müller's geoaccumulation index Igeo [35].

The sediment metals concentrations presented by [36] were used as a local geochemical background in all the calculations. 
According to the first geochemical classification of river and lake sediments in Poland, proposed by the Polish Geological Institute [24] sediments deposited at the analysed sites in the Straszyn reservoir were classified with respect to:

- $\mathrm{Zn}$ and $\mathrm{Pb}$ falling into the first class in all the sampling points

- $47 \%$ of the samples were classified to the I and 53\% to the II category in terms of Cu

- $75 \%$ of the samples were classified to the I and $25 \%$ to the II category in terms of Cd

Bojakowska [24] also reported, that the bottom sediments in northern Poland (rivers: Narew, Noteć, Łeba, Słupia) were classified in I and II category.

To establish contamination status of the Straszyn reservoir sediments, also the geoaccumulation index was calculated and classification in $\mathrm{I}_{\text {geo }}$ classes was carried out:

$$
I_{\text {geo }}=\log _{2} C_{n} / 1.5 B_{n}
$$

$\mathrm{C}_{\mathrm{n}}$ - concentration of the element " $\mathrm{n}$ " in the fraction $<0.002 \mathrm{~mm}$ (clay)

$\mathrm{B}_{\mathrm{n}}$ - background value for this element for this fraction of river sediment

The factor 1.5 is employed to take into account possible variations in the background data.

The index of geoaccumulation consists of seven grades, whereby the highest grade reflects 100 -fold enrichment above the background values. The geoaccumulation classes and corresponding contamination intensity listed by Förstner [22] were used.

In this study the values of $I_{\text {geo }}$ were calculated from using grain-size fraction of $<0.2 \mathrm{~mm}$. The Müller's geochemical index changed in a wide range: the lowest values for each metal were observed in the sampling point 1 and the highest - near the dam. The maximum value of the Müller's geochemical index was determined for copper: it was in the range 3-4 which means that the sediment was 'strongly polluted'. The values of $\mathrm{I}_{\text {geo }}$ for $\mathrm{Zn}$ and $\mathrm{Pb}$ were classified in grades 1-3: 'moderately or strongly polluted' were the samples of sediments in the middle and lower part of reservoir. Sediment of Straszyn reservoir was classified as 'unpolluted to moderately polluted' because of $\mathrm{I}_{\text {geo }}<1$ for Cd. Although the bottom sediments in Poland were classified in grades 3-4 for $\mathrm{Cu}, 3-4$ for $\mathrm{Pb}, 4-6$ for $\mathrm{Zn}$, 5-6 for Cd in river Odra [37], sediments of lake Symsar (northern Poland) were found as 'uncontaminated' and 'moderately contaminated' [9].

The graph 3 shows the mean percentages of heavy metals resistant bacteria. Bacteria isolated from sediments, raw water and drinking water displayed the highest resistance to zinc in the concentration $0.2 \mathrm{mM}$ (respectively $88 \%, 62 \%$ and $83 \%$ ). In case of lead $(0.2 \mathrm{mM})$ and copper $(0.2 \mathrm{mM})$ the percentages of strains resistant to these metals were lower and reached respectively $81 \%$ and $70 \%$ of the bacteria isolated from sediment, $54 \%$ and $50 \%$ of the bacteria isolated from the raw water and $75 \%$ and $66 \%$ in case of strains isolated from tap water. The resistance to the higher concentration $(2 \mathrm{mM})$ of copper was shown by $60 \%$ of the strains isolated from sediments, $35 \%$ of the strains isolated from the raw water and $58 \%$ from tap water. In case of bacteria resistant to $\mathrm{Zn}$ and $\mathrm{Pb}(2 \mathrm{mM})$, the figures were respectively $67 \%$ and $69 \%$ for deposits, $49 \%$ and $42 \%$ for raw water and $64 \%$ for tap water in both categories (Fig. 3).

High lead levels in drinking water are still a concern for households serviced by lead pipes in many parts of North America and Europe [38]. Copper pipes and zinc-coated components are also commonly used in water distribution systems. Many researchers point out that primarily copper and zinc ions inhibit the growth of microorganisms, but bacteria resistant to these metals are often resistant to antibiotics and disinfectants as well $[39,40]$.

According to Schwartz et al. [40] the relationship between bacteria resistance to heavy metals, antibiotics and disinfectants was observed. The disinfection process, in particular the usage of chlorine compounds may result first of all in the survival of strains resistant to both multiple-antibiotic and heavy metals [41]. One of mechanisms, by which subinhibitory levels increase the risk of selection of ARB, is the chemical stress [42].The application of chlorine solution in the disinfection process leads to the abundance of 
antibiotic-resistant bacteria and antibiotic-resistant genes in opportunistic bacteria [43, 44]. Disinfection efficiency does not remain the same throughout the supply system, as the chlorine concentration varies. Responses range from lethality/complete inhibition at high concentrations, selective survivability of resistant populations at sub-inhibiting concentrations, to responses triggering biochemical stress at much lower (sub-inhibitory) concentrations. Some of surviving bacteria may have increased the innate resistance to those impacts [45].

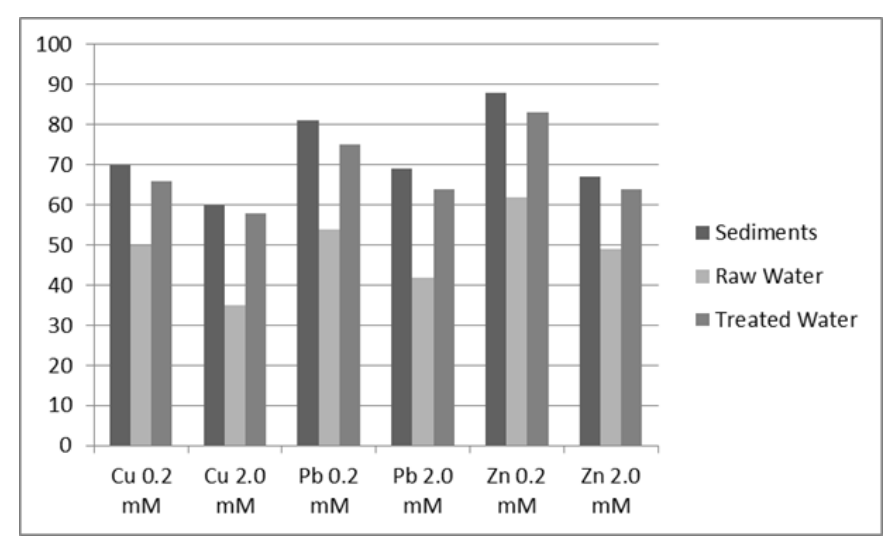

Fig. 3. The percentage of heterotrophic bacteria isolated from bottom sediments, surface raw water and tap water resistant to zinc, lead and copper.

\section{Conclusions}

The concentrations of metals in the Straszyn Lake measured in this research were lower than the contents reported by Kulbat [32] in studies conducted in 1999-2000, except copper. Accumulation of $\mathrm{Zn}, \mathrm{Cu}, \mathrm{Pb}$ and $\mathrm{Cd}$ in sediments was mainly related to content of fine fraction of sediments. The results of this study proved that sediments of Straszyn reservoir not exceed the levels of I and II class according to Polish geochemical standards proposed by Bojakowska [24]. However the maximum value of the Müller's geochemical index was determined for copper: it was in the range 3-4 which means that the sediment was 'strongly polluted'. The sediments were 'moderately or strongly polluted' of zinc and lead and unpolluted to moderately polluted' of cadmium. Bacteria isolated from sediments, raw water and drinking water displayed the highest resistance to zinc, probably because content of this metal was the highest, and the multi-stage water treatment technology has contributed to the selection of bacteria resistant to various impacts, including heavy metals.

\section{Acknowledgments}

This study was financially supported by the National Scientific Center, Poland, grant No. 1438/B/P01/2011/40.

\section{References}

1. R.A. Wuana, F.E. Okieimen, Ecology, (2011) http://dx.doi.org/10.5402/2011/402647

2. A.S. Mohammed, A. Kapri, R. Goe, Heavy-Metal Pollution: Sources, Impact and Remedies. A book chapter, (2011)

3. S. Zheng, X. Zheng, C. Chen, PLoS One 7, 11 (2012) 
4. A. Farkas, C. Erratico, L. Vigano, Chemosphere 68, 761-768 (2007)

5. P. Kelderman, A.A. Osman, Wat. Res. 41, 4251-4261 (2007)

6. A. Spain, Rev. U. Res. 2, 1-6 (2003)

7. J. Bai, B. Cui, B. Chen, K. Zhang, W. Deng, H. Gao, R. Xiao, Ecol. Model. 222, 301-306 (2011)

8. M. Wojtkowska, J. Bogacki, A. Witeska, Sci. Total Environ. 551-552, 387-392 (2016)

9. A. Kuriata-Potasznik, S. Szymczyk, A. Skwierawski, I. Cymes, Water 8, 358 (2016)

10. J. Eggleton, K.V. Thomas, Environ. Int. 30, 973-980 (2004)

11. W. Guo, X. Liu, Z. Liu, G. Li, Proc. Environ. Sci. 2, 729-736 (2010)

12. S. Huo, K.M. Yeager, B. Xi, Y. Qin, Z. He, F. Wu, J. Environ. Sci. 31, 1-11 (2015)

13. M. Świderska-Bróż, Mikrozanieczyszczenia w środowisku wodnym (Wyd. P. Wroc. 1993) (in Polish)

14. D.L. Sparks, Elements 1, 193-197 (2005)

15. E. Szarek-Gwiazda, A. Czaplicka-Kotas, E. Szalinska, Clean - Soil, Air, Water 39, 4, 368-375 (2011)

16. S. Frassinetti, G. Bronzetti, L. Caltavuturo, M. Cini, C.D. Croce, J. Environ. Pathol. Toxicol. Oncol. 25, 3, 597-610 (2006)

17. R.A. Festa, D.J. Thiele, Biology Curr. Biol. 21, 21 (2011)

18. D. Berry, C. Xi, L. Raskin, Curr. Opin. Biotechnol 17 (2006)

19. D.D. MacDonald, C.G. Ingersoll, T.A. Berger, Arch. Environ. Contam. Toxicol. 39, 20-31 (2000)

20. G.A. Burton, Limnology 3, 65-75 (2002)

21. Z. Banu, S.A. Chowdhury, D. Hossain, K. Nakagami, J. Wat. Res. Prot. 5, 239-248 (2013)

22. U. Förstner, W. Ahlf, W. Calmano, Wat. Res. Tech. 28, 8-9, 307-316 (1993)

23. W. Calmano, J. Hong, U. Förstner, Wat. Sci. Tech., 28, 8-9, 223-235 (1993)

24. I. Bojakowska, G. Sokołowska, Przegląd Geologiczny 46, 1 (1998) (in Polish)

25. G.A. Best, T. Bogacka, E. Niemirycz, International river water quality, Pollution and restoration (E\&FN SPON, London, 1997)

26. www.giwk.pl (2017)

27. J. Sastre, A. Sahuquillo, M. Vidal, G. Rauret, Anal. Chim. Acta 462, 59-72 (2002)

28. O. M. Zacheus, M.J. Lehtola, L.K. Korhonen, P.J. Martikainen, Water Res. 35 (2001)

29. F.H. Chapelle, Water microbiology and geochemistry (J. Wiley\&Sons, 1993)

30. K. Jankowska, Olańczuk-Neyman, E. Kulbat, Polish J. of Environ. Stud. 15, 6 (2006)

31. W. Tylman, K. Łysek, M. Kinder, J. Pempkowiak, Water Air Soil. Pollut. 216 (2011)

32. E. Kulbat, in: Proc. VII Int. Symp on Water Manag. and Hydraulic Eng. 369-379 (2001)

33. Raport o stanie środowiska woj. pomorskiego, WIOŚ, (2000 and 2003) (in Polish)

34. M. Strzebońska, A. Kostka, E. Helios-Rybicka, E. Jarosz-Krzemińska, Pol. J. Environ. Stud. 24, 3 (2015)

35. Müller, Geojournal 2, 108-18 (1969)

36. J. Lis, A. Pasieczna, Atlas geochemiczny Pobrzeża Gdańskiego (1999) (in Polish) 
37. L. Boszke, T. Sobczyński, G. Głosińska, A. Kowalski, J. Siepak, Pol. J. Environ. Stud. 13, 5 (2004)

38. E.J. Kim, J.E. Herrera, D. Huggins, J. Braam, S. Koshowski, Water Res. 45 (2011)

39. R.G. Crounse, W.J. Pories, J.T. Bray, R.L. Mauger, App. Environ. Geochem. (1983)

40. T. Schwartz, W. Kohnen, B. Jansen, U. Obst, FEMS Microbiol. Ecology 43, 3 (2003)

41. S. Jia, P. Shi, Q. Hu, B. Li, T. Zhang, X.X. Zhang, Environ. Sci. Technol. 49 (2015)

42. J-J. Huang, H-Y. Hu, Y-H. Wu, B. Wei, Y. Lu, Chemoshpere 90 (2013)

43. R. Shrivastava, R.K. Upreti, S.R. Jain, K.N. Prasad, P.K. Seth, U.C. Chaturvedi, Ecotoxicol. Environ. Saf. 58 (2004)

44. P. Shi, S. Jia, X.X Zhang, T. Zhang, S. Cheng, A. Li, Water Res. 47 (2013)

45. S. Khan, T.K. Beattie, C.W. Knapp, Chemosphere 152 (2016) 